\title{
Diverse salinity responses in Crithmum maritimum tissues at different salinities over time
}

\author{
Faiza Hamdani ${ }^{1,2,3}$, Arezki Derridj ${ }^{1}$, Hilary J. Rogers ${ }^{3 *}$
}

${ }^{1}$ Faculté des sciences Biologiques et des Sciences Agronomiques, Université Mouloud Mammeri de Tizi-Ouzou, 15000 Tizi-Ouzou, Algeria. 'Département des Sciences Agronomiques. Faculté des Sciences de la Nature et de la Vie. Université Kasdi Merbah Ouargla, 30000 Ouargla, Algeria. ${ }^{3}$ School Biosciences, Cardiff University, Main Building, Park Place, Cardiff, CF10 3AT, UK. *Corresponding author: rogershj@cf.ac.uk

\begin{abstract}
Crithmum maritimum (sea fennel) withstands high salinity, and to better understand how different protective mechanisms against salinity are activated, young seedlings were exposed to increasing concentrations of $\mathrm{NaCl}$ ( 0 to $512 \mathrm{mM}$ ) over six weeks. Plant survival and chlorophyll content were reduced at $>85 \mathrm{mM} \mathrm{NaCl}$ and growth was affected at $\geq 341 \mathrm{mM} \mathrm{NaCl}$. Relative water content fell and $\mathrm{Na}^{+}$accumulated more in leaves than in roots. Induction of $\mathrm{Na}^{+} / \mathrm{H}^{+}$antiporter expression reached a maximum at $427 \mathrm{mM} \mathrm{NaCl}$ in both tissues. Salinity induced the accumulation of proline, soluble sugars and glycine betaine. All three accumulated to higher levels in leaves than roots and greatest accumulation was after 6 weeks and the highest salt concentrations. Hydrogen peroxide levels fell with increasing salinity in leaves, while ascorbic acid and catalase activity rose. Overall, the most dramatic changes occurred after six weeks of saline stress but different mechanisms were activated at different salinity thresholds and in the two tissues. Key salinity thresholds in the response of Crithmum maritimum to salinity stress are identified activating different mechanisms. At $85 \mathrm{mM} \mathrm{NaCl}$ roots reach osmotic adjustment, at $171 \mathrm{mM}$ further osmolyte protection mechanisms are activated, at $256 \mathrm{mM} \mathrm{NaCl}$ leaves reach osmotic adjustment, at $341 \mathrm{mM}$ plant growth is affected and at the highest salinity tested, $512 \mathrm{mM}$, protective mechanisms are affected in leaves but not in roots.
\end{abstract}

Keywords: Crithmum maritimum $\mathrm{L}$., halophyte, $\mathrm{Na}^{+} / \mathrm{K}^{+}$antiporter, reactive oxygen species, salt stress 


\section{Introduction}

Over $6 \%$ of land and one third of world-wide irrigated land are considered saline (FAO, 2008). Algeria is no exception: long periods of dryness have resulted in outward signs of soil salinization affecting 3.2 million hectares (Szabolcs, 1989). Faced with the prospect of further dryness due to climate change, urgent measures are being taken to identify, select and introduce species adapted to local conditions. Crithmum maritimum L. (sea fennel) is a halophyte typical of coastal ecosystems that shows high salt tolerance during its vegetative growth (Ben Amor et al., 2005). In fact it has been suggested that it may be of value as an oil seed crop in semi-arid saline soils where other oil crops cannot be grown (Atia et al., 2010). Furthermore, Crithmum maritimum $\mathrm{L}$. is an aromatic plant that is rich in antioxidant compounds and is already used in the Mediterranean diet (Siracusa et al., 2011). Salt stress results in water deficit, which in turn results in osmotic stress and ionic imbalance (Flowers et al., 2015). At the cellular level one of the major effects of salinity is an accumulation of reactive oxygen species (ROS) including hydrogen peroxide $\left(\mathrm{H}_{2} \mathrm{O}_{2}\right)$, superoxide $\left(\mathrm{O}^{2--}\right)$ and hydroxyl radical $(\mathrm{OH}$.) which are damaging to cellular macromolecules (Hossain and Dietz, 2016). These cellular changes produce adverse effects on plant growth and development in salt-sensitive plants (e.g. in rice; Mahdieh et al., 2015). Several mechanisms contribute to halophyte salt tolerance. One mechanism involves sequestering salts in the vacuole to control the cellular $\mathrm{K}^{+} / \mathrm{Na}^{+}$ratio through a family of $\mathrm{Na}^{+} / \mathrm{H}^{+}$antiporters (Flowers and Colmer, 2008). Many plants also accumulate organic osmolytes in their cytoplasm (Negrão et al., 2017; Dong et al., 2015). These increase cellular water retention without affecting normal metabolic processes and include soluble sugars, proline, and glycine betaine. Proline has a protective effect on membranes, proteins and enzymes against damage from a range of abiotic stresses (Ashraf and Foolad, 2007). Glycine betaine is a quaternary ammonium compound that protects the photosynthetic machinery. It does this by accelerating the recovery of PSII from photoinactivation (Hölmstrom et al., 2000). Furthermore, it may directly or indirectly induce $\mathrm{H}_{2} \mathrm{O}_{2}$-mediated signalling that increase both the expression and the activity of antioxidant enzymes (Gill and Tuteja, 2010). Plants have evolved both non-enzymatic and enzymatic antioxidative defence mechanisms in order to mitigate the effects of increased ROS during salinity stress. Ascorbic acid is a primary substrate in the cyclic enzymatic pathway that detoxifies hydrogen peroxide (Akram et al., 2017). The enzymatic defence system consists of a battery of enzymes that interconvert ROS moieties into the less damaging $\mathrm{H}_{2} \mathrm{O}_{2}$, and then remove it. These include superoxide dismutase (SOD), catalase (CAT) and ascorbate peroxidase (APX) (Hossain and Dietz, 2016). Catalases (CAT) degrade the $\mathrm{H}_{2} \mathrm{O}_{2}$ by its dismutation to water and oxygen.

Given the interplay of these multiple detoxification and tolerance mechanisms, the current study aimed to resolve the deployment of these strategies in an Algerian population of the halophyte Crithmum maritimum. As salt concentrations were ramped up over a six week treatment period, deployment of different strategies came into play indicating a complex regulation of salt tolerance in this species. 


\section{Materials and Methods}

\subsection{Plant material and growth}

Crithmum maritimum seeds were collected from the Northern Algerian coastline (province of Tipaza: $36^{\circ}$ $35^{\prime} 22^{\prime}$ N, $2^{\circ} 26^{\prime} 50$ ” E). This area is characterized by an annual precipitation of $600 \mathrm{~mm}$ (1978-2004) (Boudjelal, 2007). The annual average temperature is around $18^{\circ} \mathrm{C}(1990-2005)$ with average temperatures around $11^{\circ} \mathrm{C}$ in winter (December-February) and 25 ${ }^{\circ} \mathrm{C}$ in summer (June -August). Crithmum maritimum grows on rocky headlands and sandstone slabs from the Pleistocene and Early Pliocene overlooking the sea. Because of the exposure of this area to salty sea winds, the plants growing here are frequently subjected to sea water spray and sea water $\left(55.38 \mathrm{dSm}^{-1}\right.$; Khelifi et al., 2013).

Seeds were sown in pots (10-15 seedlings per pot with six replicate $\mathrm{p}$ ots) containing medium coarse sand which had been washed and then dried, acting as an inert support for the plants. Following sowing, seeds were watered with distilled water. Once cotyledons appeared, plants were irrigated with a nutrient solution at pH 5.6 (Morard, 1995). Just after the first leaf pair appeared (10 days after sowing), salt treatments were applied $(\mathrm{NaCl}$ concentrations: $0,34,85,171$, $256,341,427$ and $512 \mathrm{mM}$ ) for six weeks. Six replicate pots were set up for each salt concentration in a homogeneous completely randomized design. Electrical conductivity was checked (Table 1) throughout the 6 week growing period and was constant.

All plant growth was in a Phytotron growth cabinet at $25^{\circ} \mathrm{C}$, with a photoperiod of: 16 hours light / 8 hours darkness and at $90 \mu \mathrm{mol} \mathrm{m} \mathrm{m}^{-2} \mathrm{~s}^{-1}$ using warm white fluorescent tubes. After 1, 2 and 6 weeks under saline conditions, leaves and roots were sampled randomly from more than one plant for each analysis. Roots were not washed prior to analyses as the sandy medium was easy to remove.

Table 1. Electrical Conductivity of different treatments

\begin{tabular}{ccccccccc}
\hline $\begin{array}{c}\mathrm{NaCl} \text { concentration } \\
(\mathrm{mM})\end{array}$ & 0 & 34 & 85 & 171 & 256 & 241 & 427 & 512 \\
\cline { 1 - 5 } & & & & & & & & \\
\hline $\begin{array}{c}\text { Electrical Conductivity } \\
(\mathrm{ms}) \text { at } 25^{\circ} \mathrm{C}\end{array}$ & 2.34 & 5.78 & 10.93 & 18.75 & 25 & 34.25 & 43 & 54.14 \\
& & & & & & & & \\
\end{tabular}

The $\%$ survival and plant growth were determined on the seedlings after six weeks for each of the six replicate pots. Relative growth rate (RGR) was calculated from the shoot height data over time (Wang, 2011). Relative water content (RWC) in leaves and roots, was determined on three replicate samples that were dried in an oven at $105{ }^{\circ} \mathrm{C}$ to a constant dry weight and was calculated using the following formula: RWC $(\%)=(\mathrm{FW}-\mathrm{DW}) / \mathrm{FW}$ X 100 where FW indicates fresh weight and DW indicates dry weight. 


\subsection{Metabolite analyses and enzyme activity mea-} surements

Ion $\left(\mathrm{Na}^{+}, \mathrm{K}^{+}\right)$and osmolyte (proline and soluble sugars) concentration, and chlorophyll content were measured in leaves and roots over time (after 1, 2 and 6 weeks for leaves; 2 and 6 weeks for roots). $\mathrm{Na}^{+}$and $\mathrm{K}^{+}$were analysed by flame photometry (using a Cecil 6000 series spectrophotometer). After drying for $1 \mathrm{~h}$ at $105^{\circ} \mathrm{C}, 100 \mathrm{mg}$ of each triplicate dry sample were placed in a cold muffle furnace, raising the temperature gradually to $520^{\circ} \mathrm{C}$ (for $2 \mathrm{~h}$ ) and then left overnight to cool. Following 15 mins in a desiccator, samples were dissolved in $2 \mathrm{~mL} \mathrm{HNO}_{3}(0.5 \mathrm{~N})$ and were then boiled for $20 \mathrm{~min}$. They were then filtered, and the volume was adjusted to $50 \mathrm{~mL}$ with distilled water. The $\mathrm{K}^{+} / \mathrm{Na}^{+}$ratio was calculated following analysis by flame photometry.

Chlorophyll extraction was performed as described by Plummer (1989): $100 \mathrm{mg}$ of leaf tissue (in triplicate) was ground in $80 \%$ acetone. Extracts were then centrifuged at $3000 \mathrm{rpm}$ for $10 \mathrm{~min}$ in an Eppendorf minispin microcentrifuge. Absorption of the supernatant was measured at $652 \mathrm{~nm}$. To calculate the amount of chlorophyll the formula: chlorophyll $\mathrm{mg} / \mathrm{mL}=\mathrm{ab}$ sorbance at $652 \mathrm{~nm} \times 5.8$, was used then converted to $\mu \mathrm{g} \mathrm{g}^{-1} \mathrm{FW}$.

Proline was determined by spectrophotometry (Troll and Lindsley, 1955). Plant material (triplicate samples of $100 \mathrm{mg}$ ) was suspended in $2 \mathrm{~mL}$ of $40 \%$ ethanol and heated to $85{ }^{\circ} \mathrm{C}$ in a water bath for $60 \mathrm{~min}$. After cooling, $1 \mathrm{~mL}$ of ninhydrin reagent was added (ninhydrin reagent consisted of $120 \mathrm{~mL}$ distilled water, 300 $\mathrm{mL}$ of acetic acid, $80 \mathrm{~mL}$ acetic orthophosphoric acid, at a density of 1.7 , and $25 \mathrm{mg}$ of ninhydrin). After boiling the mixture for $30 \mathrm{~min}$ and then cooling, benzene $(5 \mathrm{~mL})$ was added to each tube. The upper phase was used for the measurement of proline concentration by spectrophotometry at $528 \mathrm{~nm}$.
Soluble sugar content was measured according to the anthrone method (Plummer, 1989). Triplicate, $100 \mathrm{mg}$ plant material samples were macerated in $3 \mathrm{~mL} 80 \%$ ethanol and stored for 48 hours. Samples were heated to $70{ }^{\circ} \mathrm{C}$ for 30 minutes and then diluted 10 fold with $80 \%$ ethanol. Two $\mathrm{mL}$ of the sample were then added to $4 \mathrm{~mL}$ of anthrone reagent $(0.2 \mathrm{~g}$ of anthrone in 100 $\mathrm{mL} \mathrm{H}_{2} \mathrm{SO}_{4}$ ). The samples were heated for $8 \mathrm{~min}$ to 92 ${ }^{\circ} \mathrm{C}$, and cooled for $30 \mathrm{~min}$ on ice in the dark. Absorbance was measured at $585 \mathrm{~nm}$.

Glycine betaine was measured by spectrophotometry (Grieve and Grattan, 1983). Triplicates of plant tissue $\left(150 \mathrm{mg}\right.$ ) were dried to constant weight at $80^{\circ} \mathrm{C}$. After grinding to a fine powder, they were shaken at $25{ }^{\circ} \mathrm{C}$ with $20 \mathrm{~mL}$ deionised water for $24 \mathrm{~h}$. Samples were filtered through Whatman filter paper and filtrates were diluted to $1: 1$ with $2 \mathrm{~N} \mathrm{H}_{2} \mathrm{SO}_{4}$. Samples were cooled in ice/water for $1 \mathrm{~h}$ and then cold KI-I2 reagent $(15.7 \mathrm{~g}$ iodine and potassium iodide $(20 \mathrm{~g})$ dissolved in 100 $\mathrm{mL}$ of water) was added and they were vortexed rapidly. Following storage of the samples at $4{ }^{\circ} \mathrm{C}$ for $16 \mathrm{~h}$, they were centrifuged at $0{ }^{\circ} \mathrm{C}$ and $10,000 \mathrm{~g}$ for $15 \mathrm{~min}$ using an Allegra Beckman Coulter microcentrifuge. The supernatant was then carefully removed with a fine glass tube. The periodide crystals were dissolved in $9 \mathrm{~mL}$ of 1,2-dichloroethane. Following storage for $2 \mathrm{~h}$ at room temperature, absorbance at $365 \mathrm{~nm}$ was measured. Glycine betaine (Sigma Aldrich Poole. UK) was used as a standard, and glycine betaine content of the plant samples was expressed as $\mathrm{mg} \mathrm{g}^{-1} \mathrm{DW}$. Total solute concentration in roots and leaves over time was calculated by dividing the sum of proline, glycine betaine, soluble sugars and $\mathrm{K}^{+}$concentrations by the amount of water present in the plant tissue, based on $\%$ relative water content of the tissue.

Ascorbic acid was analyzed by HPLC following extraction using a freezing procedure (Nojavan et al., 2008). Triplicate $100 \mathrm{mg}$ samples of plant material were snap frozen in liquid nitrogen. Samples were then 
mixed with $5 \mathrm{~mL}$ of $5 \%$ metaphosphoric acid (MPA). The mixture was homogenized for $5 \mathrm{~min}$ and then was centrifuged for $10 \mathrm{~min}$ at $2000 \mathrm{rpm}$ in an Allegra Beckman Coulter microcentrifuge. All extractions were conducted at $4{ }^{\circ} \mathrm{C}$ in reduced light. HPLC analysis was performed using an isocratic elution procedure and a UV Detector at $240 \mathrm{~nm}$. Separation was on a $5 \mu \mathrm{m} \mathrm{RP} \mathrm{C18} \mathrm{column} \mathrm{of} 250 \mathrm{~mm} \times 4.6 \mathrm{~mm}$ (Kinetex-Phenomenex) with a mobile phase of $0.5 \%$ $\mathrm{NaH}_{2} \mathrm{PO}_{4}\left(\mathrm{pH} 2.25\right.$ with $\mathrm{H}_{3} \mathrm{PO}_{4}$ ) - acetonitrile ( $2 \%$ of final volume). Quantitative analyses were performed using an injection volume of $20 \mu$ l. Amber flasks were used for all standard solutions and samples to avoid loss of the ascorbic acid, due to light exposure.

After six weeks of salt stress, the $\mathrm{H}_{2} \mathrm{O}_{2}$ concentration in leaves was measured using an Amplex Red Hydrogen Peroxide/Peroxidase Assay Kit (Molecular Probes, Invitrogen). Leaf tissue (in triplicate) was ground in liquid nitrogen, then to each $50 \mathrm{mg}$ of ground frozen tissue, $500 \mu \mathrm{l}$ of phosphate buffer $\left(20 \mathrm{mM} \mathrm{K}_{2} \mathrm{HPO}_{4}\right.$, $\mathrm{pH} 6.5$ ) were added and samples were centrifuged for $5 \mathrm{~min}$ at $13000 \mathrm{rpm}$ in an Eppendorf minispin microcentrifuge. Horseradish peroxidase $\left(0.2 \mathrm{U} \mathrm{mL}^{-1}\right)$ and 100 mM Amplex Red reagent (10-acetyl-3,7-dihydrophenoxazine) were added to $50 \mu 1$ of the supernatant and the reaction was incubated at room temperature in the dark for $30 \mathrm{~min}$. Absorbance at $560 \mathrm{~nm}$ was measured using an Infinite 200 PRO microplate reader (Tecan, Switzerland).

Catalase activity was determined following the method of Aebi (1984). Leaf tissue (250 mg in triplicate) was ground with polyvinylpolypyrrolidone $(10 \% \mathrm{w} / \mathrm{w})$ and $10 \mathrm{~mL}$ of $100 \mathrm{mM} \mathrm{K}$-phosphate buffer (pH 7.0), and the homogenate filtered through four layers of cheesecloth. The filtrate was then centrifuged at $27000 \mathrm{xg}$ at $4{ }^{\circ} \mathrm{C}$ for $20 \mathrm{~min}$ and the supernatant was used for the enzyme activity assay. The enzyme extraction procedure was carried out at $0-4{ }^{\circ} \mathrm{C}$ throughout. To determine catalase activity, the reaction mixture $(1 \mathrm{~mL})$ comprised
$0.05 \mathrm{~mL}$ of enzyme extract, $50 \mathrm{mM}$ K-phosphate buffer ( $\mathrm{pH} 7.0), 0.1 \%(\mathrm{v} / \mathrm{v})$ Triton $\mathrm{X}-100$, and $0.1 \mathrm{~mL}$ of $10.5 \mathrm{mM} \mathrm{H}_{2} \mathrm{O}_{2}$ solution. The reaction was at $25^{\circ} \mathrm{C}$ for $2.5 \mathrm{~min}$. The amount of enzyme which breaks down $1 \mu \mathrm{mol}$ of $\mathrm{H}_{2} \mathrm{O}_{2} \mathrm{~min}^{-1}$ under the assay conditions described is defined as one unit of catalase activity.

\subsection{RNA extraction and Real time PCR}

RNA extractions were performed using an RNeasy Mini Kit (Qiagen) and contaminating genomic DNA was removed on the column. cDNA was synthesized using an Ambion kit (RETROscript ${ }^{\circledR}$ Reverse transcription for RT-PCR) and $2 \mu \mathrm{g}$ of extracted RNA. Real time PCR was performed using an Absolute TM QPCR SYBR ${ }^{\circledR}$ Green Mix (Thermo Scientific) kit. Reactions, in a total volume of $25 \mu 1$, contained: $5 \mu 1$ of cDNA (diluted 1:20), $12.5 \mu \mathrm{l}$ of Absolute TM QPCR SYBR ${ }^{\circledR}$ Green Mix, $1.75 \mu$ of each primer $(10 \mu \mathrm{M})$ and $4 \mu \mathrm{H}_{2} \mathrm{O}$. Triplicate reactions were cycled in an $\mathrm{MJ}$ Research OPTICON TM 2, at $95{ }^{\circ} \mathrm{C}$ for $10 \mathrm{~min}$, followed by 40 cycles of $95{ }^{\circ} \mathrm{C}$ for $15 \mathrm{~s}, 60{ }^{\circ} \mathrm{C}$ for $30 \mathrm{~s}$ and $72{ }^{\circ} \mathrm{C}$ for $30 \mathrm{~s}$ and one cycle of $72{ }^{\circ} \mathrm{C}$ for $30 \mathrm{~s}$. For verifying primer specificity, melting curve analysis (from $60{ }^{\circ} \mathrm{C}$ to $98{ }^{\circ} \mathrm{C}$ with an increasing heat rate of $\left.0.5^{\circ} \mathrm{C} \mathrm{s}^{-1}\right)$ was carried out after amplification. The relative quantification of the gene expression data was calculated using the 2- ${ }^{\mathrm{DDCT}}$ or comparative CT method (Livak and Schmittgen, 2001). Mt18S rRNA primers (Mt 18S-F: TGACGGAGAATTAGGGTTCG and Mt 18SR: CCTCCAATGGATCCTCGTTA) (El Maghrabi et $a l ., 2013)$ were used for normalization. Primers for the Crithmum maritimum antiporter gene (Na-HF: GATGTGGGAAACGGAAACC and Na-HR: CAAATTGTTGGTGCTTTGTT), were derived from alignment of sequences from Atriplex dimorphostegia (AY211397) and Atriplex gmelini (AB038492). The C. maritimum PCR products were sequenced fully 


\subsection{Statistical analyses}

Statistical analyses were performed using StatBox6 and $\mathrm{R}$ software ( $\mathrm{R}$ version 2.15.3, R Foundation for Statistical Computing). One -way or 2-way ANOVA tests were used, as appropriate, to analyse all the data sets, and where significant $(\mathrm{P}<0.05)$ interactions or mean effect were found, a Newman-Keuls test was used, consolidated by a Tukey's test.

\section{A}

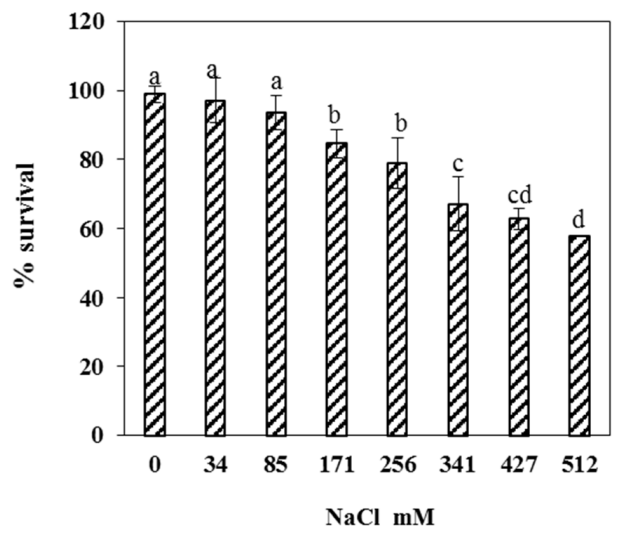

\section{Results}

3.1. Seedling survival, plant growth and chlorophyll content under saline stress

Six weeks growth under saline stress resulted in significantly reduced seedling survival above $85 \mathrm{mM} \mathrm{NaCl}$ which was reduced again at $341 \mathrm{mM} \mathrm{NaCl}(\mathrm{P}<0.05)$. At the highest concentration tested $(512 \mathrm{mM} \mathrm{NaCl})$, survival was reduced to $58 \%( \pm 3.0)$ of the non-stressed controls where survival was $99 \pm 1.7 \%$ (Figure 1A).

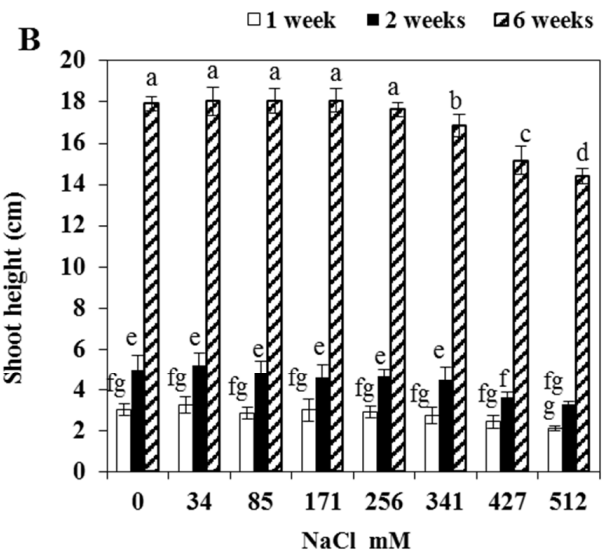

C

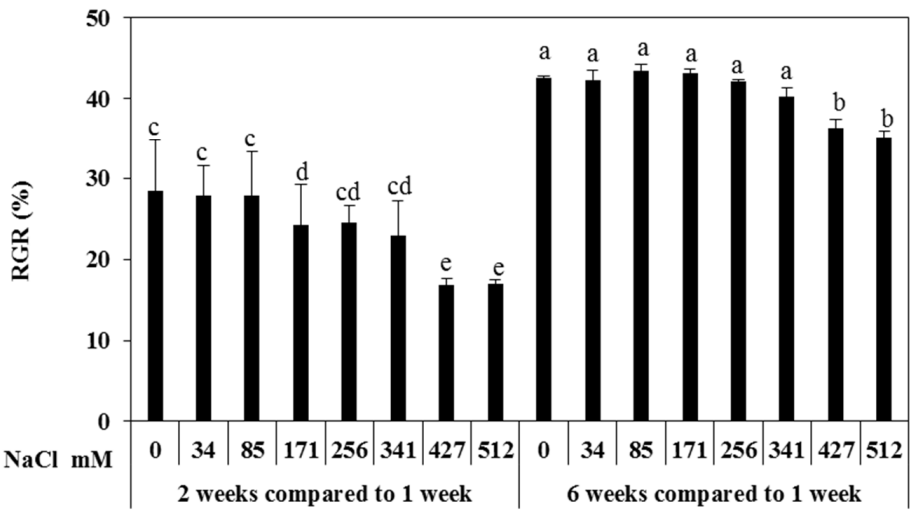

Figure 1. Growth and survival of Crithmum maritimum seedlings under salt stress. Mean percentage survival per pot after 6 weeks (A), shoot height over time per pot (B), RGR (\% shoot height) after 2 weeks compared to 1 week and 6 weeks compared to 1 week (C). Mean \pm S.D; different letters above the bars indicate significant differences based on a Tukey's test $(\mathrm{P}<0.05)$ across all samples $(\mathrm{n}=6)$. 
This was accompanied by a significant reduction in shoot height at $>341 \mathrm{mM} \mathrm{NaCl}$ with a maximum reduction at $512 \mathrm{mM}$ of $18 \%$ compared to the controls after 6 weeks (Figure 1B). The relative growth rate (RGR) of shoot height was significantly lower between the first and second week at $\mathrm{NaCl}$ concentrations $>341 \mathrm{mM}$ (Figure 1C). After 6 weeks (relative to growth after 1 week), a significant effect of salt stress on RGR was recorded at $\mathrm{NaCl}$ concentrations $>256 \mathrm{mM}$ with a further significant reduction at 427 and $512 \mathrm{mM} \mathrm{NaCl}$. Although chlorophyll levels rose during the 6 week period as the leaves developed, the effect of the salinity treatment became more pronounced with time (Figure 2A).

A

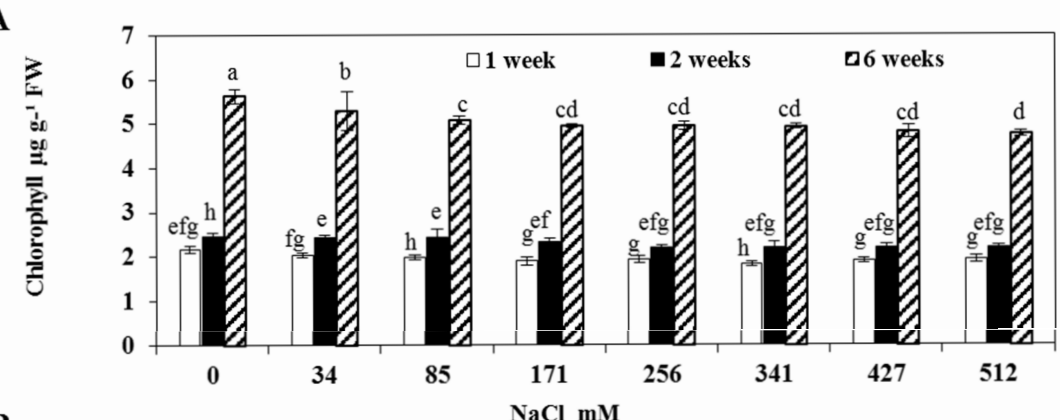

B

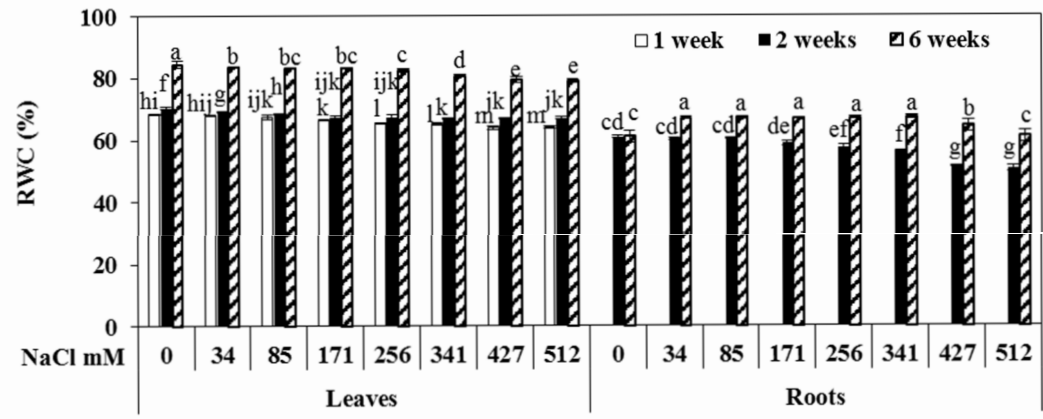

C

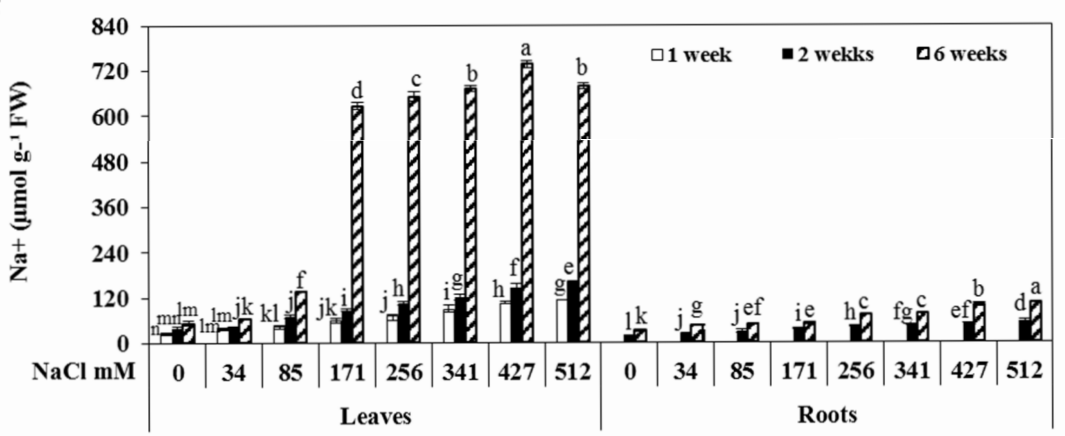

Figure 2. Chlorophyll content (A), relative water content (RWC) (B) and $\mathrm{Na}^{+}$accumulation (C) of Crithmum maritimum seedlings over time under salt stress. Mean \pm S.D; $n=3$; different letters above the bars indicate significant differences based on a Tukey's test $(\mathrm{P}<0.05)$ across all samples. 
After 2 weeks chlorophyll levels were slightly but significantly reduced at all salinity concentrations; at 6 weeks the effects of salinity treatments could be divided into three tiers. The first tier is represented by the control plants which had the highest chlorophyll content. At $34 \mathrm{mM} \mathrm{NaCl}$ concentration and above, chlorophyll levels were reduced, and the effect was significantly greater at 85 to $512 \mathrm{mM} \mathrm{NaCl}$.

\subsection{Ion accumulation $\mathrm{Na}^{+} / \mathrm{H}^{+}$antiporter gene ex-} pression and relative water content in seedling roots and leaves under saline stress.

In both leaves and roots, relative water content (RWC) fell significantly with increasing $\mathrm{NaCl}$ concentration, but rose with time (Figure 2B). After 6 weeks relative water content was affected differentially in roots and leaves. Leaf relative water content fell significantly at $\mathrm{NaCl}$ levels of just $34 \mathrm{mM}$ whereas in roots, it was in fact higher at $34 \mathrm{mM}$ $\mathrm{NaCl}$ compared to no salt controls but then remained stable until $427 \mathrm{mM} \mathrm{NaCl}$. The magnitude of the effect also differed significantly $(\mathrm{P}<0.05)$ : while leaves lost only $6 \%$ of their relative water content, roots lost $9 \%$.

The increase in $\mathrm{Na}^{+}$was significantly higher $(\mathrm{P}<$ 0.05 ) in leaves compared to the roots (Figure 2C). The difference became more pronounced over time with about a 3 -fold difference after 2 weeks and a 6 -fold difference after 6 weeks at the highest salt concentration tested. Effects of salinity treatments also differed between the two organs. In leaves the effect of salinity became much more pronounced after 6 weeks of treatment with a sudden almost 6-fold increase between $85 \mathrm{mM}$ and $171 \mathrm{mM}$ treatments. In the roots, however, the sudden increase in $\mathrm{Na}^{+}$occurred at a higher concentration of $\mathrm{Na}^{+}$ $(256 \mathrm{mM})$ and was less dramatic with only a 1.4- fold increase, although a further 1.4- increase was noted between 341 and $427 \mathrm{mM} \mathrm{NaCl}$.

In control seedlings, $\mathrm{K}^{+}$levels increased in both leaves and roots over time, to a similar extent (1.6-fold increase between 2 and 6 weeks; Figure 3A). Following 2 weeks of treatment, $\mathrm{K}^{+}$levels in seedling leaves were relatively constant at most salt treatment concentrations compared to the control. However, after 6 weeks $\mathrm{K}^{+}$concentration fell significantly, by $19 \%$, at $512 \mathrm{mM}$ (607 \pm 8 compared to the control at $747 \pm 16 \mu$ molg $^{-1}$ FW). This pattern was different from that in roots: here $\mathrm{K}^{+}$accumulation fell substantially (by $24 \%$ ) even after only two weeks at $512 \mathrm{mM} \mathrm{NaCl}$ compared to the control $\left(57 \pm 2\right.$ compared to the control at $75 \pm 3 \mu \mathrm{molg}^{-1}$ FW; Figure 4A). After six weeks of salt treatment at

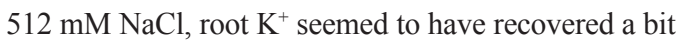
as it was only $18 \%$ lower than the control $99 \pm 2$ compared to the control at $120 \pm 4 \mu \mathrm{molg}^{-1} \mathrm{FW}$.

Changes in relative $\mathrm{K}^{+}$and $\mathrm{Na}^{+}$concentrations resulted in a fall of the $\mathrm{K}^{+} \mathrm{Na}^{+}$ratio with $\mathrm{NaCl}$ increases at all three time points in both seedling leaves and roots (Figure 3B). However, the pattern of change differed markedly between time points and between the two organs. Whereas the decrease was gradual at the earlier time points in both organs, by 6 weeks there was a dramatic decrease in $\mathrm{K}^{+}$ $\mathrm{Na}^{+}$ratio in leaves between 85 and $171 \mathrm{mM} \mathrm{NaCl}$ treatments. In roots however, there seemed to be a more gradual decline in the ratio with increasing salinity.

The changes in $\mathrm{K}^{+}$and $\mathrm{Na}^{+}$accumulation were reflected in an induction of the Crithmum maritimum $\mathrm{Na}^{+} / \mathrm{H}^{+}$ antiporter gene expression in leaves and roots under salt treatment (Figure 3C). Expression increased significantly at $\geq 256 \mathrm{mM} \mathrm{NaCl}$ in leaves and rose to a maximum expression at $427 \mathrm{mM} \mathrm{NaCl}$ before falling back at $512 \mathrm{mM} \mathrm{NaCl}$. In roots the pattern of induction was similar: expression was induced at a lower salinity of $171 \mathrm{mM} \mathrm{NaCl}$ but again reached a maximum at $427 \mathrm{mM} \mathrm{NaCl}$ before falling back at the highest salt concentration tested. 
$\mathbf{A}$
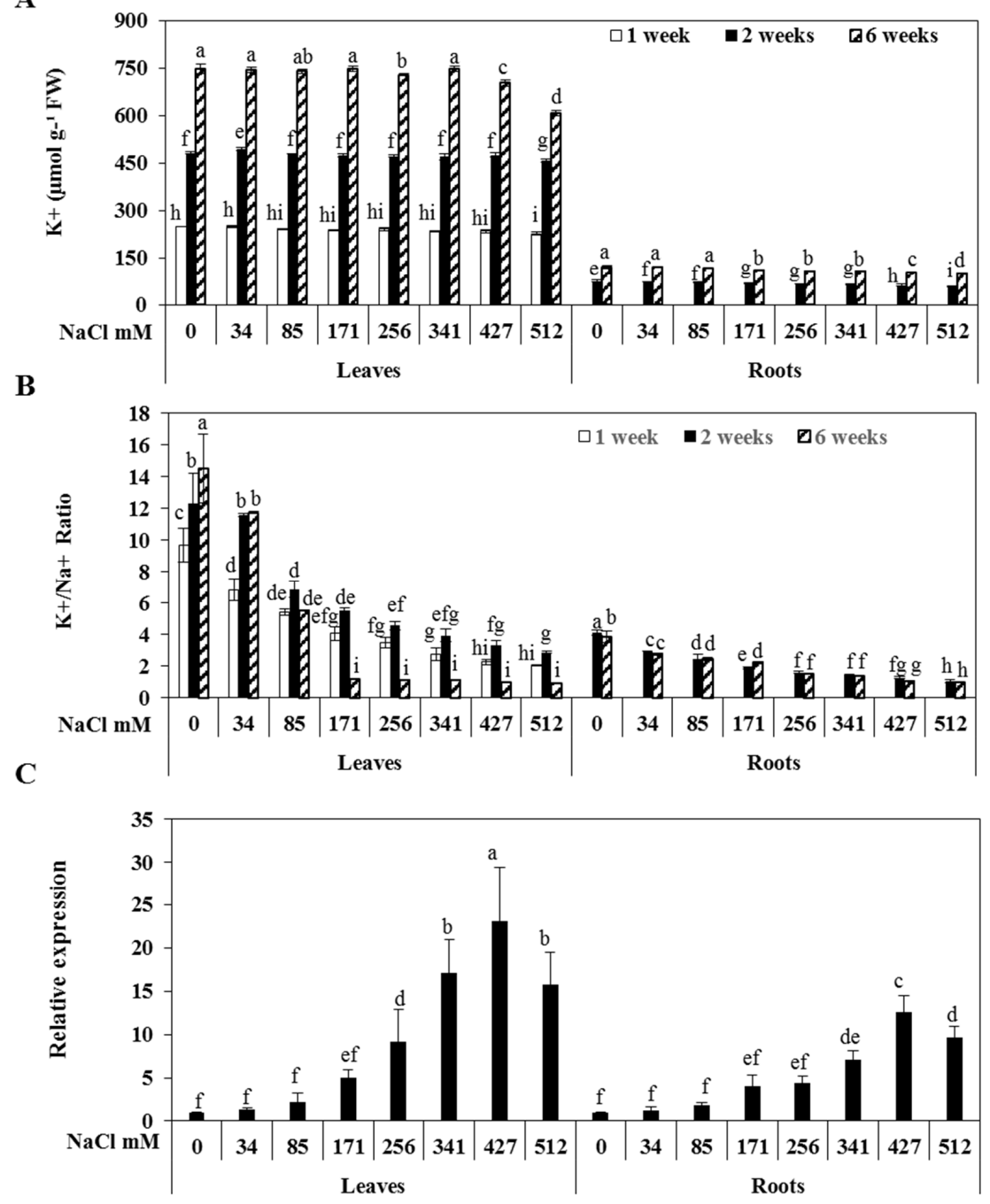

Figure 3. $\mathrm{K}^{+}$accumulation (A), $\mathrm{K}^{+} / \mathrm{Na}^{+}$ratio (B) of Crithmum maritimum seedlings over time under salt stress. Relative $\mathrm{Na}^{+} / \mathrm{H}^{+}$antiporter expression $(\mathrm{C})$ after 6 weeks under salt treatment. Mean $\pm \mathrm{S} . \mathrm{D} ; \mathrm{n}=3$ (A and B); $\mathrm{n}=$ 6 (C); different letters above the bars indicate significant differences based on a Tukey's test $(\mathrm{P}<0.05)$ across all samples. 


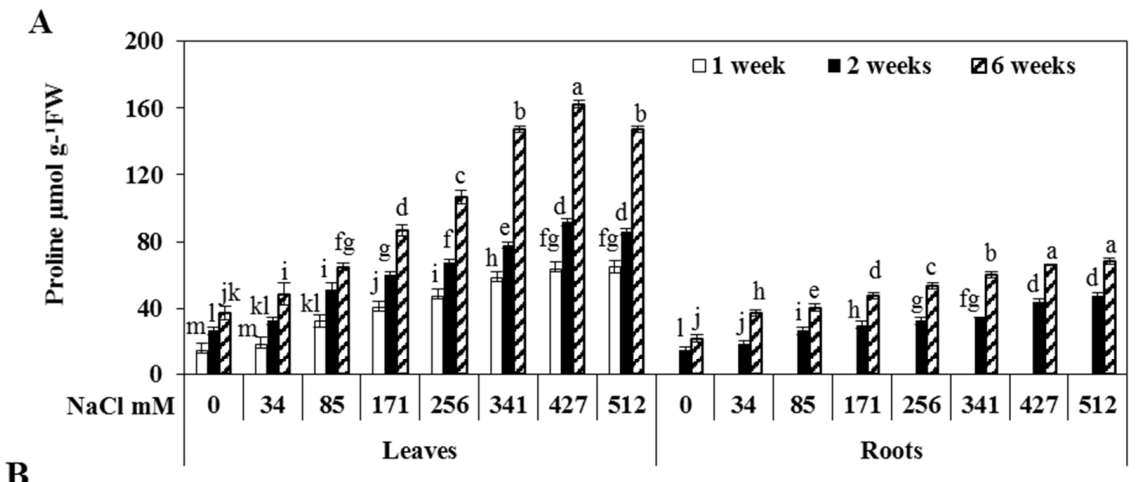

B

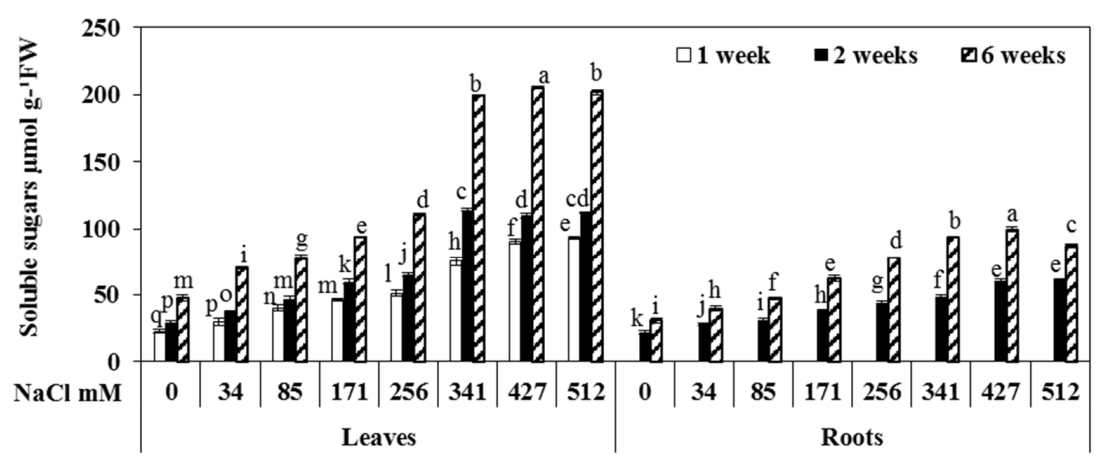

C

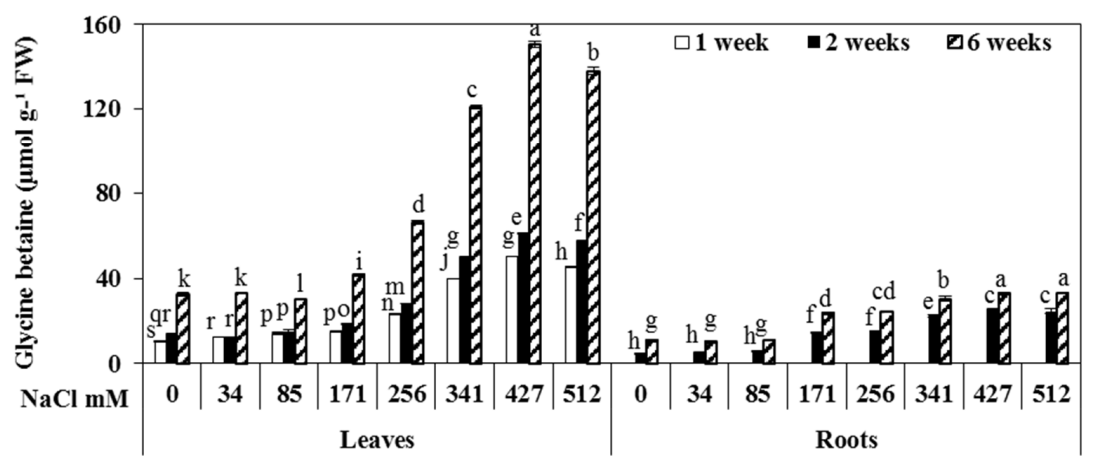

Figure 4. Proline concentration (A), soluble sugars concentration (B) and glycine betaine concentration of Crithmum maritimum seedlings over time under salt stress. Mean \pm S.D; $n=3$ (A and B); $n=6$ (C); different letters above the bars indicate significant differences based on a Tukey's test $(\mathrm{P}<0.05)$ across all samples. 


\subsection{Induction of osmolyte accumulation in leaves and roots}

There was a significant increase in proline in both the leaves and the roots with increasing $\mathrm{NaCl}$ concentrations. However after 1 week the maximal concentration of proline in the leaves was recorded at the highest two $\mathrm{NaCl}$ concentrations tested $(427 \mathrm{mM}$ and $512 \mathrm{mM}$; Figure 4A) while after 2 and 6 weeks, proline concentration peaked at $427 \mathrm{mM}(162 \pm 2$ $\mu \mathrm{mol} \mathrm{g}{ }^{-1} \mathrm{FW}$ ) and then fell back at $512 \mathrm{mM} \mathrm{NaCl}$. In contrast, root proline concentration continued to increase with increasing salt concentration up to and including $512 \mathrm{mM} \mathrm{NaCl}$ even after 6 weeks of treatment. After 6 weeks of treatment there was a marked rise in proline between 256 and $341 \mathrm{mM}$ $\mathrm{NaCl}$ in leaves, whereas this threshold effect was not seen in the roots.

Soluble sugar concentration in leaves and roots also rose significantly with increasing time and $\mathrm{NaCl}$ concentration (Figure 4B). However, the 256 to 341 $\mathrm{mM}$ threshold effect noted with proline concentration in leaves, was seen with leaf soluble sugars after only 2 weeks as well as after 6 weeks and again was not evident in the roots. In leaves, soluble sugar concentration reached a maximum at $427 \mathrm{mM} \mathrm{NaCl}$ with only a slight reduction in level at the highest salt concentration. In contrast soluble sugar accumulation in roots after 6 weeks clearly peaked at 427 $\mathrm{mM} \mathrm{NaCl}$ and fell significantly at $512 \mathrm{mM} \mathrm{NaCl}$. Glycine betaine accumulation was also induced with increasing salinity. In leaves again a threshold effect between 256 to $341 \mathrm{mM} \mathrm{NaCl}$ was evident after 6 weeks and concentrations fell at the highest salinity tested (Figure 4C). In roots however, after
6 weeks, there were two notable rises in glycine betaine concentration: between 85 and $171 \mathrm{mM}$ and between 256 and $341 \mathrm{mM} \mathrm{NaCl}$. Furthermore, in roots glycine betaine concentrations remained high even at the highest salt concentration tested whereas in leaves they fell significantly at 512 $\mathrm{mM} \mathrm{NaCl}$. Over time, glycine betaine concentrations increased significantly in both tissues at most salt concentrations, however the most dramatic increases were seen at the higher $\mathrm{NaCl}$ concentration between 2 and 6 weeks in leaves.

In leaves the total internal solutes were greater than external solute concentration up to about $256 \mathrm{mM}$ $\mathrm{NaCl}$, while in roots this threshold was reached at $85 \mathrm{mM} \mathrm{NaCl}$, indicating that this is the point at which osmotic adjustment occurs. However, this is clearly an estimate, as other cellular solutes which were not measured here will contribute to the total internal solute concentration (Figure 5).

3.4 Antioxidant capacity and catalase activity rose with increasing salinity, while ROS levels fell.

Leaf $\mathrm{H}_{2} \mathrm{O}_{2}$ concentration fell significantly between control (no salt) and plants exposed to the highest two salt concentrations (Figure 6A). In contrast seedling leaves accumulated ascorbic acid in response to saline treatment with a linear increase with increasing $\mathrm{NaCl}$ concentration from 34-512 $\mathrm{mM} \mathrm{NaCl}$ (Figure 6B) and the highest accumulation at $512 \mathrm{mM}$. Catalase activity was also induced by the saline treatment in leaves of $C$. maritimum. However the activity was only consistently greater than control levels at $256-427 \mathrm{mM} \mathrm{NaCl}$, falling back again at $512 \mathrm{mM} \mathrm{NaCl}$ (Figure 6C). 


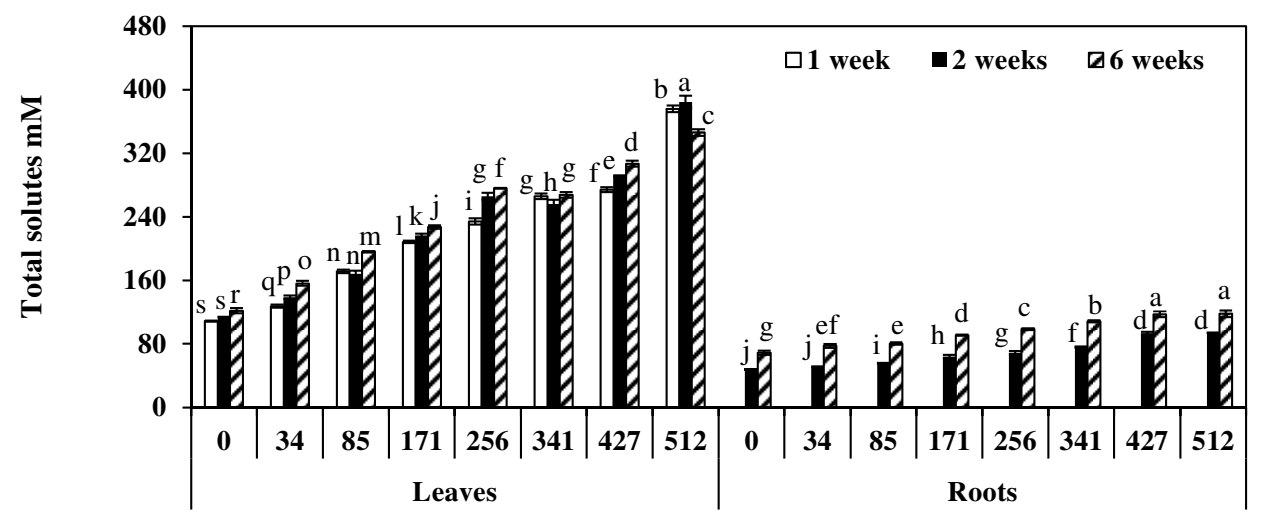

Figure 5. Total internal solutes (expressed in $\mathrm{mM}$ ) of Crithmum maritimum seedlings over time against total external solutes comprising $\mathrm{NaCl}(0,34,85,171,256,341,427,512 \mathrm{mM})$ and total nutrient solutes of $32.1 \mathrm{mM}$. Mean \pm S.D; $n=3$; different letters above the bars indicate significant differences based on a Tukey's test $(\mathrm{P}<$ $0.05)$ across all samples. 
A

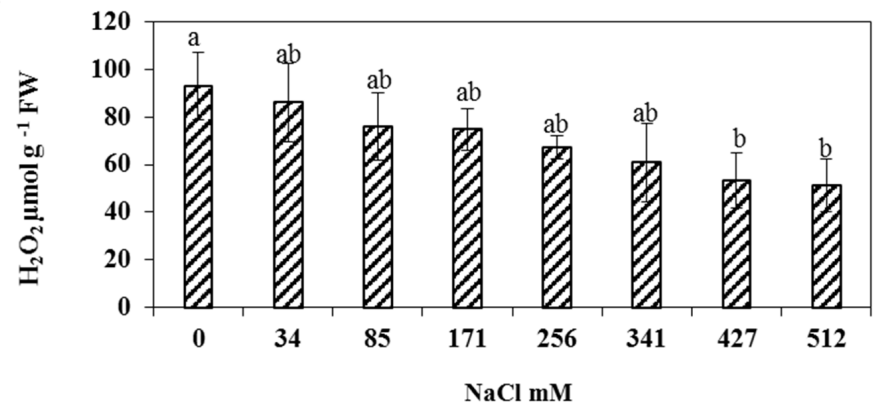

B

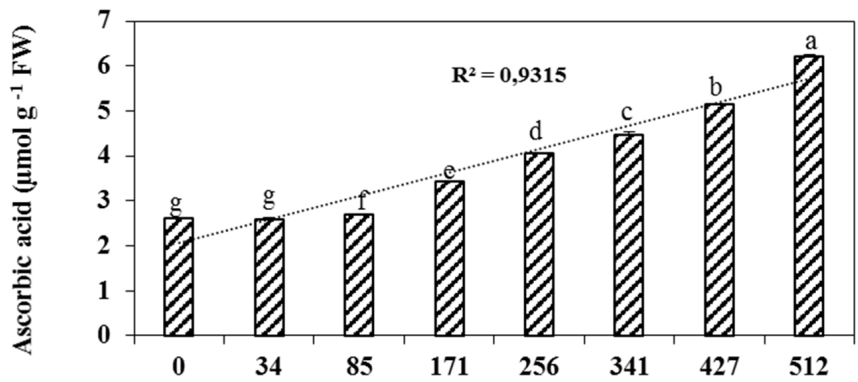

C

$\mathrm{NaCl} \mathbf{m M}$

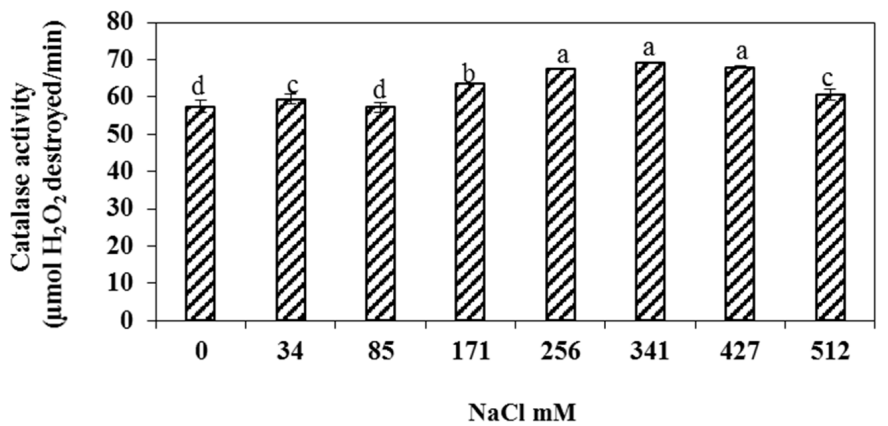

Figure 6. $\mathrm{H}_{2} \mathrm{O}_{2}$ concentration (A), Ascorbic acid concentration (B) and catalase activity (C) in leaves of Crithmum maritimum seedlings. After 6 weeks (means \pm S.D ; $\mathrm{n}=3$; different letters above the bars indicate significant differences based on a Tukey's test $(\mathrm{P}<0.05)$ across all samples for $\mathrm{B}$ and $\mathrm{C}$, while for $\mathrm{A}$, letters indicate differences based only on the salt concentration. 


\section{Discussion}

The reduced growth of C. maritimum under elevated salt treatments was in agreement with previous reports (Ben Hamed et al., 2004; Ben Hamed et al., 2007; Ben Amor et al., 2005). However here effects on shoot height were only significant at $\geq 341 \mathrm{mM}$ $\mathrm{NaCl}$ whereas in the Tunisian population studied by Ben Hamed et al. (2004), biomass after 5 weeks as well as leaf number and total leaf area were affected even at $150 \mathrm{mM} \mathrm{NaCl}$. This suggests that the Algerian population studied here was substantially more salt tolerant. Ben Hamed et al. (2004) saw no chlorosis even at $300 \mathrm{mM} \mathrm{NaCl}$. The more sensitive chlorophyll measurements made here indicate some loss of chlorophyll even at low salt concentrations of $>34$ $\mathrm{mM}$ after similar periods of treatment, although losses were relatively small even at the highest salt concentrations applied. This suggests that the salt stress imposed was not inducing premature senescence as it does on less salt-tolerant species (e.g. pomegranate; Mastrogiannidou et al., 2016), although it may be contributing to the reduced growth even in halophytes such as $C$. maritimum through reduced carbon fixation as previously suggested (Flowers and Colmer, 2008). The apparently better growth of the plants in their natural habitat was ascribed by Ben Hamed et al. (2004) to small differences in growth conditions or, more likely, a protection of the root system from extremes of salt due to their growth in rock crevices. The Algerian population used here also grew vigorously very close to the sea indicating a similar protection of the roots from the saline water.

Maintaining a high $\mathrm{K}^{+} / \mathrm{Na}^{+}$ratio is likely to be important to avoid effects of ion toxicity under salt stress (Flowers et al., 2015). Although this ratio dropped dramatically with increasing salinity, even after 6 weeks it remained relatively constant between 171 and $512 \mathrm{mM} \mathrm{NaCl}$. A clear difference was seen, however, in the accumulation of $\mathrm{Na}^{+}$between roots and shoots, consistent with the studies of Tunisian $C$. maritimum populations (Ben Hamed et al., 2004; Ben Amor et al., 2005). In both the Tunisian C. maritimum (Ben Hamed et al., 2004), and the Algerian population reported here, there was a sudden increase in shoot $\mathrm{Na}+$ accumulation at $>100 \mathrm{mM} \mathrm{NaCl}$. However, whereas in the Tunisian $C$. maritimum roots, $\mathrm{Na}^{+}$accumulation plateaued after $100 \mathrm{mM} \mathrm{NaCl}$, the Algerian $\mathrm{C}$. maritimum roots continued to accumulate increasing $\mathrm{Na}^{+}$concentrations with increasing salinity up to the maximal level of $512 \mathrm{mM}$ tested. Thus, the increased tolerance to salinity seen in the Algerian population here is not due to better exclusion of the $\mathrm{Na}^{+}$from the roots. Leaf relative water content changes also differed between the Algerian C. maritimum presented here and the Tunisian populations previously studied (Ben Hamed et al., 2004; Ben Amor et al., 2005). Whereas the relative water content remained stable in the Tunisian C. maritimum populations, here a significant loss in relative water content was seen at concentrations of $>85 \mathrm{mM} \mathrm{NaCl}$. In contrast, root relative water content remained much more stable up to 427 $\mathrm{mM} \mathrm{NaCl}$, linked presumably to the lower accumulation of $\mathrm{Na}^{+}$. In both tissues, loss of relative water content seems to be linked to $\mathrm{Na}^{+}$accumulation of $>$ $100 \mu \mathrm{molg}^{-1} \mathrm{FW}$, which may therefore be a threshold level of $\mathrm{Na}^{+}$before water retention is affected. Differences between the Algerian and Tunisian C. maritimum response may also be due to the maturity of the plants used since the Tunisian C. maritimum plants were already 1 month (Ben Amor et al., 2005) or 2 months (Ben Hamed et al., 2004) old when the saline treatments were applied. Alternatively the method of treatment may have affected the outcome: here salinity was imposed directly to simulate natural conditions where changes in salinity can occur rapidly; the previous studies (Ben Hamed et al., 2004; Ben Amor et al., 2005) applied the salinity treatments gradually. 
Despite the increases in $\mathrm{Na}^{+}$accumulation, $\mathrm{K}^{+}$concentrations remained remarkably stable up to $427 \mathrm{mM}$ $\mathrm{NaCl}$ in leaves, while there was a gradual decline in root $\mathrm{K}^{+}$concentration from $171 \mathrm{mM} \mathrm{NaCl}$. This again contrasts with the previous studies (Ben Hamed et al., 2004; Ben Amor et al., 2005) where both leaf and root $\mathrm{K}^{+}$concentrations fell dramatically between the no salt control and a $50 \mathrm{mM} \mathrm{NaCl}$ treatment. Again, this suggests a better resilience of the Algerian population to the salt stress. Part of this resilience may be due to the induction of the $\mathrm{Na}^{+} / \mathrm{H}^{+}$antiporter gene expression, which rises significantly at $\geq 256 \mathrm{mM}$ and 171 $\mathrm{mM} \mathrm{NaCl}$ in leaves and roots respectively. It is assumed, based on experimental evidence from other halophytes (Flowers and Colmer, 2008) that the activation of the antiporter in C. maritimum is important for $\mathrm{Na}^{+}$sequestration into the vacuole. Its activation in both organs contrasts with Mesembryanthemum crystallinum $\mathrm{L}$ where expression of subunit $\mathrm{E}$ of the vacuolar $\mathrm{H}^{+}$-ATPase, required for $\mathrm{Na}^{+}$transport into the vacuole, was only upregulated in leaves but not roots in response to salt (Golldack and Dietz, 2001). However the M. crystallinum gene expression was only studied following a very short salt exposure of $72 \mathrm{~h}$ so it may be that both root and leaf $\mathrm{Na}^{+}$transport into the vacuole only become important after prolonged salt exposure. The reduction in expression of the C. maritimum $\mathrm{Na}^{+} / \mathrm{H}^{+}$antiporter at $512 \mathrm{mM} \mathrm{NaCl}$ in both organs is presumably linked to a failure of the salt tolerance mechanisms which may be down-regulating transcription of many genes and which is also seen in the significant reduction of shoot height and $\mathrm{K}^{+}$ concentration at this level of salinity.

Despite the importance of osmolyte production in halophytes, known to mitigate effects of saline stress by providing cytoplasmic osmotic adjustment (Flowers et al., 2015), to our knowledge this is the first analysis of these metabolites in C. maritimum. All three osmolytes analysed here: proline, glycine betaine and soluble sugars accumulated with increasing salt concentrations as has been found for other halophytes (Flowers and Colmer, 2008). Increase in proline was not as high as is some halophytes such as Mesembryanthemum crystallinum L., where the increase is > 10-fold (Sanada et al., 1995) but its concentration was still significantly (3 to 4-fold) induced. It was proposed (Tipirdamaz et al., 2006), that there was an inverse relationship between proline and glycine betaine accumulation amongst halophyte species. However, C. maritimum does not appear to follow this trend since both osmolytes accumulated to similar extents in both roots and leaves. All three osmolyte concentrations increased substantially between 256 and $341 \mathrm{mM} \mathrm{NaCl}$ suggesting that as salinity rises above $300 \mathrm{mM}$ osmolytes become particularly important in C. maritimum. Concentrations of all three osmolytes also fell in leaves at $512 \mathrm{mM} \mathrm{NaCl}$ supporting the hypothesis that at this high salt level transcription and/ or biosynthetic pathways are being affected. At this salt level, the concentration of soluble sugars fell back also in roots, however concentrations of proline and glycine betaine remained stable suggesting that their biosynthesis was not being inhibited, and that at this very high salt concentration their action as osmolytes may be important for cellular protection. By considering the total concentration of solutes measured here, which are considered to be the major contributors to osmotic adjustment (Singh et al., 2015) it was possible to estimate the concentration at which osmotic adjustment occurs. Unlike some other halophytes such as Atriplex mummularia (Silveira et al., 2009) osmotic adjustment appeared to occur in both leaves and roots of C.maritimum. However, this occurred at very different concentrations of external salts: with roots the osmotic adjustment occurred at $85 \mathrm{mM} \mathrm{NaCl}$ maximally, while in leaves that maximum was reached at $171 \mathrm{mM}$. One reason proposed for a growth reduction at high salinity is an increase in 
reactive oxygen species causing cellular damage. A rise in markers for lipid peroxidation has been seen in several halophytes at $>300 \mathrm{mM} \mathrm{NaCl}$ even over short treatments (Ben Hamed et al., 2007). However an increase in ROS seems an unlikely explanation for the growth effects in C. maritimum. $\mathrm{H}_{2} \mathrm{O}_{2}$ concentrations in fact decreased with increasing salinity while ascorbic acid concentrations rose, indicating that redox status was not adversely affected. Catalase activity also increased with salinity indicating an induction of protective antioxidant mechanisms which may be resulting in the maintenance of redox balance. This contrasts with a previous report on a Tunisian population of C. maritimum (Ben Hamed et al., 2007) where $\mathrm{H}_{2} \mathrm{O}_{2}$ concentrations rose while ascorbic acid concentrations and catalase activity fell as salinity was increased to $300 \mathrm{mM} \mathrm{NaCl}$. This further suggests that the Algerian population studied here is less affected by the salinity. A fall in $\mathrm{H}_{2} \mathrm{O}_{2}$ and induction of CAT activity in response to increased salinity has been reported for other halophytes (e.g. Atriplex halimus and Nitraria retusa, Boughalleb et al., 2010) indicating that the response of the C. maritimum population reported here is not entirely anomalous.

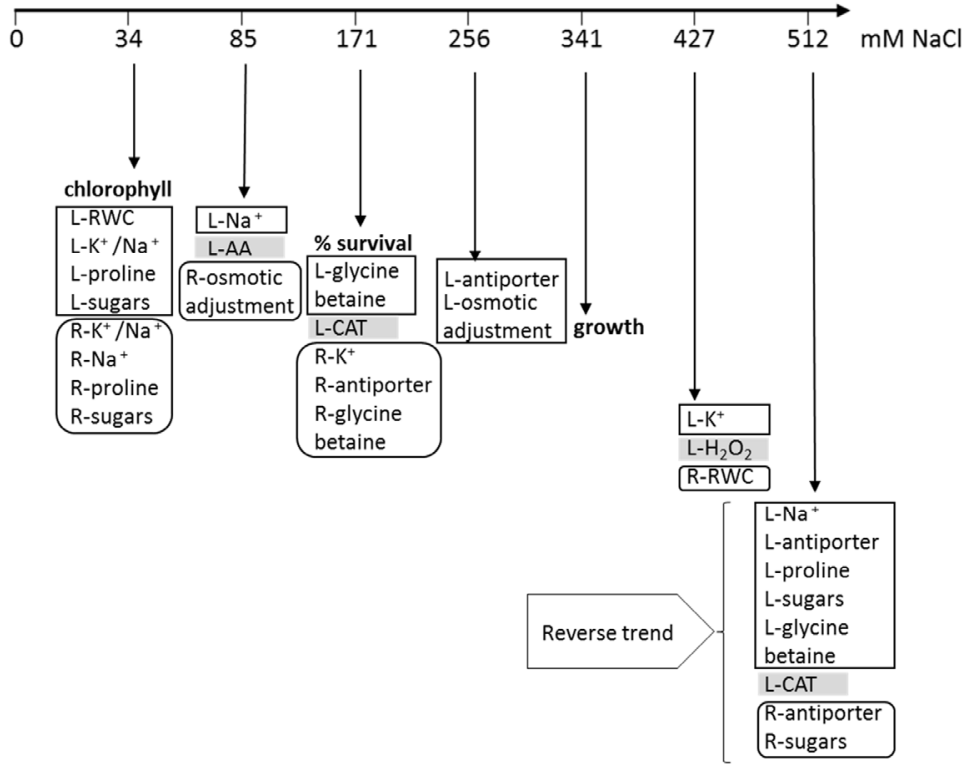

Figure 7. Diagram of changes in physiological (bold), metabolite, enzyme activity and gene expression changes with increasing salinity after 6 weeks growth of Crithmum maritimum. L= leaf (square box); R = root (rounded box); RWC (relative water content); shaded box = ROS regulation. 


\section{Conclusions}

Overall the response to increased salinity in this population of Crithmum maritimum seems to involve concentration thresholds which activate different tolerance mechanisms (Figure 7). Already at $34 \mathrm{mM} \mathrm{NaCl}$ concentration, some osmolyte production is upregulated, but protective mechanisms in leaves, and some signals of stress are evident. At $85 \mathrm{mM} \mathrm{NaCl}$ roots reach osmotic adjustment, and at $171 \mathrm{mM}$ further osmolyte protection mechanisms are upregulated in both, leaves and roots but \% survival has been compromised. At 256 $\mathrm{mM} \mathrm{NaCl}$ leaves reach osmotic adjustment and at 341 $\mathrm{mM}$ plant growth is affected suggesting that tolerance mechanisms are struggling to overcome the stress. Finally at $512 \mathrm{mM}$ all leaf osmolyte levels but only soluble sugars fall in roots, and catalase activity is reduced, indicating that at this very high salinity concentration, most protective mechanisms in leaves are unable to be sustained. In roots however, where $\mathrm{Na}^{+}$concentrations are still increasing, stress is less severe enabling some growth to continue.

\section{Acknowledgements}

We thank Mike O'Reilly for assistance with the metabolite analyses. This work was supported by the Algerian Government and Cardiff University, UK.

\section{References}

Aebi, H. 1984. Catalase in vitro. Methods in Enzymology. 105, 121-126.

Akram, N.A., Shafiq, F., Ashraf, M. 2017. Ascorbic acid - a potential oxidant scavenger and its role in plant development and abiotic stress tolerance. Front. Plant Sci. 8, 613.
Ashraf, M., Foolad, M.R. 2007. Roles of glycine betaine and proline in improving plant abiotic stress resistance. Env. and Exper. Bot. 59, 206-216

Atia, A.A., Debez, A., Barhoumi, Z., Abdelly, C., Smauoi, A.R. 2010. Localization and composition of seed oils of Crithmum maritimum L. (Apiaceae). African J. of Biotechnol. 39, 6482-6485.

Ben Amor, N., Ben Hamed, K., Debez, A., Grignon, C., Abdelly, C. 2005. Physiological and antioxidant responses of the perennial halophyte Crithmum maritimum to salinity. Plant Sci. 168, 889-899.

Ben Hamed, K., Debez, A., Chibani, F., Abdelly, C. 2004. Salt response of Crithmum maritimum, an oleagineous halophyte. Tropical Ecol. 45, 151159.

Ben Hamed, K., Castagna, A., Elkahoui, S., Ranieri, A., Abdelly, C. 2007. Sea fennel (Crithmum maritimum L.) under salinity conditions: a comparison of leaf and root antioxidant responses. Plant Growth Reg. 53, 185-194.

Boudjelal, A.A. 2007. Determination of the water needs of crops using cropwat 4.3 software in the province of Tipaza. Thesis to obtain the status of engineering degree in Agronomy. National Agronomy Institute, Algeria, $95 \mathrm{p}$.

Boughalleb, F., Mhamdi, M., Hailaoui, H., Denden, M. 2010. Salinity effects on organic solutes and antioxidative enzymes in two halophytes, $\mathrm{Ni}$ traria retusa (Forssk) and Atriplex halimus (L.). Research J. of Biol. Sci. 5, 773-784.

Dong, Y.J., Wang, Z.L., Zhang, J.W., Liu, S., He, Z.L., He, M.R. 2015. Interaction effects of nitric oxide and salicylic acid in alleviating salt stress of Gossypium hirsutum L. J. Soil Sci. Plant Nut. 15, 561-573.

El Maghrabi, A.M., Ochatt, S., Rogers, H.J., Francis, D. 2013. Enhanced tolerance to salinity following cellular acclimation to increasing $\mathrm{NaCl}$ levels in Medicago truncatula. Plant Cell Tissue and Organ Culture. 114, 61-70. 
Flowers, T.J., Colmer, T.D. 2008. Salinity tolerance in halophytes. New Phytol. 179, 945-963.

Flowers, T.J, Munns, R., Colmer, T.D. 2015. Sodium chloride toxicity and the cellular basis of salt tolerance in halophytes. Ann. Bot. 115, 419-431.

Gill, S.S., Tuteja, N. 2010. Reactive oxygen species and antioxidant machinery in abiotic stress tolerance in crop plants. Plant Physiol. and Biochem. 48, 909-930.

Golldack, D., Dietz, K.J. 2001. Salt-induced expression of the vacuolar $\mathrm{H}^{+}$-ATPase in the common ice plant is developmentally controlled and tissue specific. Plant Physiol. 125, 1643-1654.

Grieve, C.M., Grattan, S.R. 1983. Rapid assay for determination of water soluble quaternary ammonium compounds. Plant and Soil. 70, 303-307.

Hölmstrom, K.O., Somersalo, S., Mandal, A., Palva, T.E., Welin, B. 2000. Improved tolerance to salinity and low temperature in transgenic tobacco producing glycine betaine. J. Exp. Bot. 51, 177-185.

Hossain, M.Z., Dietz, KJ. 2016. Tuning of Redox Regulatory Mechanisms, Reactive Oxygen Species and Redox Homeostasis under Salinity Stress. Front. Plant Sci. 7, 548.

Khelifi, H., Bioret, F., Farsi, B. 2013. Apport à la connaissance syntaxonomique du littoral rocheux ouest-algérois. Acta Bot. Gallica. 155, 163-177.

Livak, K.J., Schmittgen, T.D. 2001. Analysis of relative gene expression data using real-time quantitative PCR and the 2-DDCT method. Methods. $25,402-408$.

Mahdieh, M., Habibollahi, N., Amirjani, M,R., Abnosi, M.H., Ghorbanpour, M. 2015. Exogenous silicon nutrition ameliorates salt-induced stress by improving growth and efficiency of PSII in Oryza sativa L. cultivars. J. Soil Sci. Plant Nut. 15, 1050-1060.
Mastrogiannidou, E., Chatzissavvidis, C., Antonopoulou, C., Tsabardoukas, V., Giannakoula, A., Therios I. 2016. Response of pomegranate cv. wonderful plants to salinity. J. Soil Sci. Plant Nut. 16, 621-636.

Morard, P. 1995. Above ground vegetable crops. Agricultural publications Agen, Paris, 304 p.

Negrão, S., Schmöckel, S. M., Tester, M. 2017. Evaluating physiological responses of plants to salinity stress. Annals of Botany. 119, 1-11.

Nojavan, S., Khalilian, F., Momen Kiaie, F., Rahimi, A., Arabanian, A., Chalavi, S. 2008. Extraction and quantitative determination of ascorbic acid during different maturity stages of Rosa canina $\mathrm{L}$. fruit. J. Food Composition and Anal. 21, 300-305.

Plummer, D.T. 1989. Introduction to Practical Biochemistry. McGraw-Hill, Paris, 331p.

Sanada, Y., Ueda, H., Kuribayashi1, K., Andoh, T., Hayashi, F., Tamai, N., Wada, K. 1995. Novel light-dark change of proline levels in halophyte (Mesembryanthemum crystallinum L.) and glycophytes (Hordeum vulgare L. and Triticum aestivum L.) leaves and roots under salt stress. Plant Cell Physiol. 6, 965-970.

Silveira, J.A.G., Araújo, S.A.M., Lima, J.P.M.S., Viégas, R.A. 2009. Roots and leaves display contrasting osmotic adjustment mechanisms in response to $\mathrm{NaCl}$-salinity in Atriplex nummularia. Env. and Exp. Bot. 66, 1-8.

Singh, M., Kumar, J., Singh, S. 2015. Roles of osmoprotectants in improving salinity and drought tolerance in plants: a review. Rev. Env. Sci. Biotechnol. 14, 407-426.

Siracusa, L., Kulisic-Bilusic, T., Politeo, O., Krause, I., Dejanovic, B., Ruberto, G. 2011. Phenolic composition and antioxidant activity of aqueous infusions from Capparis spinosa L. and Crithmum maritimum $\mathrm{L}$. before and after submission to a two-step in vitro digestion model. J. Agric. Food Chem. 59, 12453-12459. 
Szabolcs, I. 1989. Salt affected soils. CRP Press Inc, Boca Raton, Florida.

Tipirdamaz, R., Gagneul, D., Duhaze, C., AÏınouche, A., Monnier, C., Özkum, D., Larher, F. 2006. Clustering of halophytes from an inland salt marsh in Turkey according to their ability to accumulate sodium and nitrogenous osmolytes. Env. and Exp. Bot. 57, 139-153.
Troll, W., Lindsley, J. 1955. A photometric method for the determination of proline. J. of Biol. Chem. 215, 655-660.

Wang, Y. 2011. The adaptation Mechanism of Leymus chinensis to grazing and salt-alkali stress. MSc Thesis, University of Hohenheim, Germany, $49 \mathrm{pp}$. 